\title{
Determinants of Saving and Investment Behaviour of Tea Plantation Workers: An Empirical Analysis of Four Tea Gardens of Udalguri \\ District (Assam) \\ Dipali Bosumatari
}

\begin{abstract}
The main objective of this paper is to examine the main determinants of saving and investment behaviour of tea plantation workers in Assam based on a microeconomic approach. Four tea gardens have been selected for the purpose of data collection. These gardens are Bhooteachang Tea Estate, Hattigor Tea Estate, Brotherhood Tea Growing firm and Jwnglari Tea Farm. Two separate multiple linear regression models were fitted for saving and investment. The paper found that there is propensity to save and invest among the tea planation workers in spite of low income. The workers in the sample save their income mainly in SBI, LIC, and other banks and invest in children's education and other income generating activities like rearing livestock, buying cultivated land, etc. Further, it is found that income level, education status, occupation have positive influence on saving, while the number of dependents exerts a negative influence on saving. The factors that drive household investment are occupation, income and assets.
\end{abstract}

Keywords: Tea garden, Saving, Investment, Plantation community.

\subsection{Introduction}

Household saving is of utmost importance in the formation of physical assets in every economy. The households undertake a substantial portion of the physical investment directly and they also make public and private corporate investment. Saving is normally considered in economics as disposable income minus personal consumption expenditure. In other words, it is regarded as income that is not consumed immediately in buying goods and services.

Dipali Bosumatari, Ph.D. Research Scholar, School of Economics, University of Hyderabad, Hyderabad. 
By not using income to buy consumer goods and service, it is a resource which will be invested to produce tangible and intangible capital such as machinery, schooling, on-the-job training, among others. Saving can therefore be vital for increasing the amount of capital available. For developing economies, saving and investment are necessary engines for capital formation and hence economic growth. It has been argued that saving constitutes the basis for capital formation and capital formation constitutes a critical determinant of economic growth. The traditional view in this regard is that rural households are too poor and for that matter cannot make any meaningful saving and investment choices. In this context, there is the need to carefully understand the determinants of both the household saving rate and the saving pattern.

Households' saving and investment behaviour is influenced by several factors like the perception of saving of those who save, their ability, willingness, objectives and motivations for saving and the opportunity to save. In this connection, Schmidt et al (1992), Panickar (1992), Kraay (2000), Athukorala and Sen (2001) and Horioka and Wan (2007) analysed the determinants of saving and investment in different countries and in different time period and found that income has positive and significant influence on saving and investment. They found that household saving and investment is positively influenced by income and wealth of the households. They rightly found that people near subsistence level of consumption will have lower average saving rates than richer people as the share of their income available for smoothing consumption is smaller. Income has a decisive role to play in determining the savings by the households. Whereas the lower income households find it difficult to meet their current expenditure, the higher income groups could save a large portion of their income.

Studies of Left (1969), Repetto and Shah (1975), Loayza et al. (1998), Chandra and Long (2003) and Issahaku (2011) found that demographic variables such as the urbanization ratios, age and dependency ratio have a significantly negative impact on private saving rate. They found that savings and investment behaviour of households are largely influenced by ability, willingness, opportunity, the perception, objectives or motivations of the household.

Further, studies by Raj (1962), Friend (1966), Bhalla (1978), Sharma (1979), Mody (1983), Krishnamurthy and Saibaba (1981) and Krishnamurthy (1996) found that occupation of the head of the household is another factor that 
affect the saving and investment behaviour. It is generally assumed that person with better occupation has higher income and better working condition. Besides, people with better occupation earn higher income and have better ability to save and invest in any form. Therefore, occupation has a positive impact on saving and investment.

Several questions arise from the above discussion. Do rural households in tea plantation have a significant capacity to save? If so, in what form(s) do they save and what factors influence saving and investment behaviour among plantation community? This is because may be most studies carried out other aspects of tea planation workers but no one has examined saving and investment behaviour. Further, many studies have carried out at the aggregate level without any or much substantive work on the household sector. Thus, to formulate or design appropriate theories or policies to boost saving and investment in the plantation economy, it is important for one to better understand and appreciate the saving and investment characteristics of plantation community. Therefore, in this study an attempt has been made to understand the saving and investment characteristics or behaviour of households taking plantation working community as a case study. Plantation community is generally very poor and has less access to the mainstream society. Therefore, taking plantation community as a case study will offers a fair opportunity to verify the view held by some economists that poor households do not save. Further, the study will provide empirical evidence of the factors that engender saving and investments of tea plantation workers. Thus, it will help to guide the concerned authority and other development actors to incorporate these factors in their development plans. The present paper is organised into eight sections where section one is introduction; section two explains data source and methodology; section three outlines the model specification; section four gives income distribution of households; section five explains determinants of saving; section six explains determinants of investment; section seven gives estimated results and analysis; and section eight gives conclusions. 


\subsection{Objectives and Data Sources}

The main objectives of the paper are:

(i) to analyse different forms of saving and investment among sample tea plantation community and

(ii) to examine the various factors influencing saving and investment behaviour of plantation community

The entire paper is based on primary data. Total four tea gardens are selected from Udalguri district of Assam. These gardens are Bhooteachang Tea Estate, Hattigor Tea Estate, Brotherhood Tea Growing firm and Jwnglari Tea Farm. From these selected four gardens we have selected a total of 240 sample households, 60 households from each garden randomly. For appropriate responses from the sample households, interviews and discussions were vigorously pursued about saving and investment. Questionnaires were designed and used so as to facilitate the collection of data from households and key informants.

\subsection{Specification of the Model}

A linear saving and investment function is adopted from Rogg (2000) and Kibet et al. (2009). This study assumes linearity because the aim of the study is to test whether there is any association between the variables under study, assuming the causality. Separate regression models were fitted respectively for the determinants of saving and investment behaviour. For this model, total number of households available for private saving is selected. Level of education/attainment is the independent variable after quantifying into scale ranges from 0-5 (Scale 0 as illiterate; 1 as lower primary education level; 2 as primary education level, 3 as high school level; 4 as higher secondary and 5 graduation and above).

Hence, the exact model is that individual's total annual saving is a function of educational level or attainment of that individual, total income of the household and ratio of number of working family members to total family members which is given in equation form as follows:

$$
\mathrm{S}=f\left(\mathrm{P}_{1}, \mathrm{P} 2, \mathrm{P} 3\right)
$$


where, $\mathrm{S}=$ Household private saving, $\mathrm{P}_{1}=$ Level of education of an individual, $\mathrm{P}_{2}$ $=$ Household total income, $\mathrm{P}_{3}=$ and ratio of number of working family members to total family members (Earners' Ratio)

In order to test the above equation, Ordinary Least Square (OLS) method is used for checking linear relationship between household private saving and independent factors. The model to be fitted is given below:

$$
\mathrm{S}=\mathrm{e}^{\alpha} \mathrm{P}_{1}^{\beta} \mathrm{P}_{2}^{\gamma} \mathrm{P}_{3}^{\theta}
$$

Taking $\log$ and adding an error term,

$$
\begin{aligned}
& \ln S=\alpha+\beta \cdot \ln P_{1}+\gamma \ln P_{2}+\theta \ln P_{3}+\mu \\
& \text { where, } \alpha=\text { intercept } \\
& \beta, \gamma, \theta=\text { coefficients (to be estimated), } \\
& \mu=\text { error }
\end{aligned}
$$

Further, to examine the determinants of investment, three main variables are selected. The model for the determinant of investment is individual's total annual investment is a function of educational level or attainment of that individual, total income of the household and ratio of subsidiary income to household total income which is given in equation form as follows

$$
Y=f\left(X_{1}, X_{2}, X_{3}\right)
$$

where, $\mathrm{Y}=$ Household investment, $\mathrm{X}_{1}=$ Level of education of an individual, $\mathrm{X}_{2}=$ Household total income, $\mathrm{X}_{3}=$ Ratio of subsidiary income to $\mathrm{HH}$ total income.

In order to test the above equation, Ordinary Least Square (OLS) method is used for checking linear relation between household private investments and persuading factors. The model to be fitted is given below:

$$
\mathrm{S}=\mathrm{e}^{\alpha} \mathrm{X}_{1}{ }^{\beta} \mathrm{X}_{2}^{\gamma} \mathrm{X}_{3}{ }^{\theta}
$$

Taking log and adding an error term,

$$
\begin{aligned}
& Y=\alpha+\beta \cdot X_{1}+\gamma X_{2}+\theta X_{3}+\mu \\
& \ln Y=\alpha+\beta \cdot \ln X_{1}+\gamma \ln X_{2}+\theta \ln X_{3}+\mu \\
& \text { Where, } \alpha=\text { intercept } \\
& \beta, \gamma, \theta=\text { coefficients (to be estimated), } \\
& \mu=\text { error }
\end{aligned}
$$

\subsection{Income Distribution of Households}

The households in the gardens are heterogeneous comprising of both the rich and poor, yet there is huge number of potentials to save and invest among 
them. Rich households with higher income, better education and better jobs can always save and invest more than poor households. The garden community where there is lack of specialisation, households engages themselves in different types of income earning activities like rearing cattle, poultry, piggery, agricultural work, and some other activities. Those households whose disposable incomes are more than respective consumption expenditures either save or invest on extra income generated activities or in their children's education. Therefore, it is found that, sample workers do also practise saving and investment activities in the sample gardens.

Now the question is who saves, how much they save and where do they save are main questions as the economy of garden workers is concerned. To examine these questions, entire sample households are distributed into two category (a) households with saving and (b) households without saving (Table 1). Out of total 240 sample households only 49.8 per cent sample households practise saving and remaining 50.2 per cent households recorded to have no saving account. This means that about 50 per cent sample workers do not practise saving activity in the sample gardens.

Table 1: Distribution of Sample Households by Financial Saving

\begin{tabular}{|l|c|c|c|c|}
\hline \multicolumn{1}{|c|}{ Gardens } & $\begin{array}{c}\text { HH with } \\
\text { Saving }\end{array}$ & $\begin{array}{c}\text { Per } \\
\text { centage }\end{array}$ & $\begin{array}{c}\text { HH without } \\
\text { Saving }\end{array}$ & $\begin{array}{c}\text { Per } \\
\text { centage }\end{array}$ \\
\hline Bhooteachang & 40 & 66.7 & 20 & 33.3 \\
\hline Hattigor & 41 & 67.2 & 20 & 31.8 \\
\hline Brotherhood & 20 & 33.3 & 40 & 66.7 \\
\hline Jwnglary & 19 & 31.7 & 41 & 68.3 \\
\hline Total & 120 & 49.8 & 120 & 50.2 \\
\hline \multicolumn{5}{|l}{ Source: Calculated by Author from Field Survey Data, 2011 } \\
\hline
\end{tabular}

The saving distribution of sample households of the present study is given in the Table 2. The Table shows that the sample households of the present study save their left out income in different forms. Some households save in insurance company and some are in banks like SBI, UCO, Cooperative bank, etc. Therefore, it is clear that sample household save their income not only in banks but also in insurance companies. The data shows that the highest saving is made 
in Insurance Company followed by State Bank of India and other banks. About 36.1 per cent of households in the sample save their income in insurance company and 18.3 per cent in SBI. There are about 2.5 per cent sample households who save in other banks such as co-operative, UCO, Gramin bank and post office, etc. There are also households who save in both LIC and SBI. Further, some households do save their income in many forms such as LIC, Other bank and SBI, etc. Among the four selected sample gardens, the highest number of households of Bhooteachang tea estate have saving in LIC. Similarly, very few households about 5 per cent of Brotherhood and 13.3 per cent in Jwnglary tea estates have saved in LIC Company.

Table 2: Different Forms of Saving among Households in the Sample

\begin{tabular}{|l|c|c|c|c|c|c|c|c|}
\hline \multirow{2}{*}{$\begin{array}{c}\text { Forms of } \\
\text { Saving }\end{array}$} & \multicolumn{2}{|c|}{ Bhooteachang } & \multicolumn{2}{c|}{ Hattigor } & \multicolumn{2}{c|}{ Brotherhood } & \multicolumn{2}{|c|}{ Jwnglary } \\
\cline { 2 - 10 } & $\mathrm{HH}$ & $\begin{array}{c}\text { Per } \\
\text { cent }\end{array}$ & $\mathrm{HH}$ & $\begin{array}{c}\text { Per } \\
\text { cent }\end{array}$ & HH & $\begin{array}{c}\text { Per } \\
\text { cent }\end{array}$ & HH & $\begin{array}{c}\text { Per } \\
\text { cent }\end{array}$ \\
\hline LIC & 40 & 66.6 & 36 & 59.0 & 3 & 5 & 8 & 13.3 \\
\hline SBI & 7 & 11.7 & 6 & 9.8 & 18 & 30 & 13 & 21.7 \\
\hline Other Banks & 4 & 6.7 & 2 & 3.3 & 0 & 0 & 0 & 0 \\
\hline LIC+SBI & 8 & 13.3 & 3 & 4.9 & 2 & 3.3 & 1 & 1.7 \\
\hline $\begin{array}{l}\text { LIC+Other } \\
\text { Banks }\end{array}$ & 4 & 6.7 & 0 & 0.0 & 0 & 0.0 & 0 & 0.0 \\
\hline Source: Calculated by Author from Field Survey Data, 2011 & & & & \\
\hline
\end{tabular}

The reason behind the higher number of households saving of Bhooteachang and Hattigor tea estates in LIC is due to the introduction of LIC scheme among the permanent workers. In this scheme every willing workers can save from their wage/salary in LIC in every month. Every month at the time of wages payment the gardens authority deducts some amount from their wages or salary for LIC. So, every willing worker can save from their monthly income for different time period. Therefore, total 40 out of 60 households in Bhooteachang tea estate and 36 out of 60 households in Hattigor tea estate save their income in LIC. 
The sample households, along with saving, invest some part of their income. The data on household shows that private investment of sample households comprises of (a) investment on children's education and (b) investment on income generating activities at home or locality. According to survey data, about 76.35 per cent sample households invest either in children's education or other income generating activities. Out of total 240 sample households only 23.6 per cent sample households do not have record on investment. The garden wise distributions also show that almost all samples do invest their income in different activities. Table 3 indicates that household workers of Brotherhood tea estate have the highest record with investment which is around 83.3 per cent followed by Hattigor tea estate $(78.7$ per cent) and Bhooteachang tea estate ( 75 per cent). On the other hand, Jwnglary tea estate has the least record which is 68.30 per cent in the sample study.

Table 3: Investment Behaviour of Sample Households

\begin{tabular}{|l|c|c|c|c|c|}
\hline \multirow{2}{*}{$\begin{array}{c}\text { Name of the } \\
\text { Gardens }\end{array}$} & \multicolumn{2}{|c|}{$\begin{array}{c}\text { HH with } \\
\text { Investment }\end{array}$} & \multicolumn{2}{c|}{ HH without Investment } \\
\cline { 2 - 5 } & $\begin{array}{l}\text { Total } \\
\text { HH }\end{array}$ & $\begin{array}{l}\text { Per } \\
\text { cent }\end{array}$ & Total HH & Per cent \\
\hline Bhooteachang & 45 & 75.00 & 15 & 25.00 \\
\hline Hattigor & 48 & 78.70 & 13 & 21.31 \\
\hline Brotherhood & 50 & 83.30 & 10 & 16.67 \\
\hline Jwnglary & 41 & 68.30 & 19 & 31.67 \\
\hline Total & 184 & 76.35 & 56 & 23.65 \\
\hline Source: Author's Calculation from Field Survey Data, 2011 \\
\hline
\end{tabular}

With many effort of concerned authority, the concept of education has been spread among the working community of tea plantation. They also realised the importance of education in their daily life as well as professional life. Therefore, many working community in the sample gardens have started educating their children. Thus, investment in education of their children has increased considerably. The Table 4 indicates that out of total sample households about 65.14 per cent are investing on their children's education. It further showed 
that Hattigor tea estate has showed the highest investment in children education followed by Brotherhood and Bhooteachang tea gardens. Jwnglary tea estate recorded to have least (50 per cent) investment in children education.

Besides, many households do also invest in other income generated activities such as investing in livestock rearing, buying lands, etc. Out of total sample households 30.3 per cent of sample households invest their income in these activities. The main income generating activities in the sample gardens are investing in livestock rearing and buying lands. Rearing cow, Bullocks, Pigs, Goat/ Sheep, poultry are very much common to the plantation workers because these are the main source of income for the plantation workers. Almost all sample household rear different kinds of livestock. The reasons behind the engaging in such activities are due to fact that working community in the tea garden receives very less amount of wage or salary. It is very difficult on the part of the labour family to manage their daily needs with their less earning. Therefore, many sample households take up to invest their income in other income generating activities to increase their family income further. According to them, investing in other income generating activities helps in increasing their income level. Further, they said that, the benefit received from these activities take less time as compared to investment in education. Therefore, many able households try investing in other income generating activities to increase their income level.

Table 4: Forms of Investment among the Sample Households

\begin{tabular}{|l|c|c|c|c|c|c|}
\hline \multirow{2}{*}{ Gardens } & \multicolumn{2}{|c|}{ Education } & \multicolumn{2}{c|}{$\begin{array}{c}\text { Other Income } \\
\text { Generated } \\
\text { Activities }\end{array}$} & \multicolumn{2}{c|}{$\begin{array}{c}\text { Education and other } \\
\text { income generated } \\
\text { activities }\end{array}$} \\
\cline { 2 - 8 } & HH & Per cent & HH & Per cent & HH & Per cent \\
\hline Bhooteachang & 40 & 66.7 & 21 & 35.0 & 16 & 26.7 \\
\hline Hattigor & 44 & 72.1 & 19 & 31.2 & 14 & 23.0 \\
\hline Brotherhood & 43 & 71.7 & 15 & 25.0 & 8 & 13.3 \\
\hline Jwnglary & 30 & 50.0 & 18 & 30.0 & 7 & 11.7 \\
\hline Total & 157 & 65.1 & 73 & 30.3 & 44 & 18.7 \\
\hline Source: Author's Calculation from Field Survey Data, 2011 \\
\hline
\end{tabular}




\subsection{Determinants of Saving}

The deliberate decision on the part of the households to save in order to meet future needs depends on a number of factors. The factors normally considered as the determinants of saving include all the factors that affect the ability to save, the will to save and the opportunity to save. Further, the households' saving behaviour is also influenced by demographic factors. Demographic factors like age of the head of the household, number of dependent and size of the households also influence the household saving either through their impact on the ability to save or through their impact on the will to save. These factors have both positive and negative effects depending on the extent or rate of increase or decrease. Some of these important factors which affect the saving behaviour of sample workers are discussed briefly.

\subsection{Education and saving}

The first and foremost important factor which affects the saving behaviour of the sample households is education. The education of the head of the household has direct influences on the saving behaviour of the sample household. It is assumed that, higher level of education is associated with better occupation, higher income and hence higher saving. Therefore, it is obvious that more educated head of households have more ability to save as compared to no or less educated one. To examine the impact of education on saving behaviour of sample household, the level of education is classified under different category. These are illiterate head of the family, primary education, middle school education, high school education, and higher secondary education and household with graduate and above. The relationship between education and saving of the households is given in Table 5.

The survey data shows that there is positive relationship between saving and level of education of the head of the households. Household head with no education and primary education have lower saving. The average earning of head of the household with no education or illiterate is Rs. 32159 and the average saving of these households is Rs.4509 in a year. On the other hand, head of the household with higher secondary level of education has about Rs.68652 average 
earning and Rs. 18800 saving annually. Further, the average earning of head of the households with BA and above educational qualification has very high earning of Rs.72390 and average saving of Rs. 28000 in a year. From this it is clear that higher level of education encourages occupying better job and higher income and as a result higher ability to save.

Table 5: Educational Status of Respondents and their Saving

\begin{tabular}{|l|c|c|c|c|c|}
\hline $\begin{array}{c}\text { Level of } \\
\text { Education }\end{array}$ & $\begin{array}{c}\text { Total } \\
\text { HH }\end{array}$ & \multicolumn{2}{|c|}{ HH with Saving } & Average & $\begin{array}{c}\text { Average } \\
\text { Saving }\end{array}$ \\
\cline { 3 - 6 } & & $\begin{array}{l}\text { Ter } \\
\text { centage }\end{array}$ & & \\
\hline Illiterate & 140 & 46 & 32.9 & 32159 & 4509 \\
\hline Primary & 9 & 5 & 55.6 & 35154 & 4350 \\
\hline Middle & 48 & 31 & 64.6 & 41154 & 5480 \\
\hline High School & 36 & 29 & 80.6 & 47154 & 8820 \\
\hline Class XI-XII & 6 & 6 & 100.0 & 68652 & 18800 \\
\hline BA and Above & 2 & 2 & 100.0 & 72390 & 28000 \\
\hline Source: Calculated by Author From Field Survey Data \\
\hline
\end{tabular}

\subsection{Occupation and saving}

The occupation of the head of the household plays an important role in differentiating saving among the households. The occupation in the tea garden of sample households are classified under manual workers, agricultural workers, petty businessman, clerk, drivers, sardars, office staffs and artisans. The classification of sample households according to their occupation is given in the Table 6. According to survey data, about 65 per cent of sample workers of the present paper are engaged in manual workers whose average income is Rs. 26154 in a year. These households save about Rs.4960 annually from their total income. The income and saving of the cultivator households is lower as compared to that of the salaried class and, the self-employed in non-agricultural activities. Out of the total sample households about 7 per cent of the garden households are 
engaged in agricultural activities. Both income and saving of these households are much lower among the sample households.

Table 6: Occupation of Head of the Households' and Average Saving

\begin{tabular}{|l|c|c|c|c|c|}
\hline Occupation & $\begin{array}{c}\text { Total } \\
\text { HH }\end{array}$ & $\begin{array}{c}\text { No. HH } \\
\text { with } \\
\text { Saving }\end{array}$ & $\begin{array}{c}\text { \% share of } \\
\text { the total } \\
\text { workers }\end{array}$ & $\begin{array}{c}\text { Average } \\
\text { Income }\end{array}$ & $\begin{array}{c}\text { Average } \\
\text { Saving }\end{array}$ \\
\hline Manual Workers & 163 & 59 & 36.2 & 22617 & 3313 \\
\hline Agricultural Workers & 15 & 6 & 40.0 & 22308 & 3083 \\
\hline Sardars & 10 & 7 & 70.0 & 28457 & 3334 \\
\hline Clerk & 21 & 20 & 95.2 & 31500 & 4063 \\
\hline Drivers & 11 & 9 & 81.8 & 41719 & 4744 \\
\hline Business & 9 & 6 & 66.7 & 51800 & 7016 \\
\hline Office Staffs & 12 & 12 & 100.0 & 61765 & 7683 \\
\hline \multicolumn{5}{|l|}{ Source: Calculated by Author from Field Survey Data, 2011 } \\
\hline
\end{tabular}

In the sample study, there are also households whose head of the family are engaged in fixed income earning. Sarder, clerk, driver and office staffs earn fixed salary. The households head with fixed income earners have higher propensity to save compared to the manual income earners households as shown in the Table 6.

\subsection{Income and saving}

Income is another most important determinant for household saving among the tea plantation community. It is assumed that the ability of a household to save depends greatly on the income of the head of the household. To examine the effect of income on saving behaviour of sample households we have classified entire sample households into five different income groups. The classified households according to their income groups are given in table 7 . It is clearly visible from Table 7 that income has a decisive role to play in determining the saving behaviour of the households. Maximum sample households earn below Rs.30, 000 annually in sample gardens. About 85 per cent of sample household in sample tea gardens falls under the income group ranging from 
Rs.10, 000 to Rs.30, 000. The average income of these households is very low as compared to other groups. As a result their average saving is also less as compared to other groups. On the other hand, about 0.41 per cent households are recorded to have income ranges of above Rs. 100,000 among the sample households. These households save on an average of Rs.13840 annually. This average saving of higher income group shows higher than the lower income group. Thus it is clear that there is a strong and positive correlation between income and saving.

Table 7: Average Income and Saving of Different Income Groups

\begin{tabular}{|l|c|c|c|c|c|}
\hline Income Groups & No. of & \multicolumn{2}{|c|}{ HH with saving } & \multirow{2}{\text{Average}}{$\begin{array}{c}\text { Average } \\
\text { Income }\end{array}$} & Saving \\
\cline { 3 - 4 } & HH & Total No & $\begin{array}{l}\text { Per } \\
\text { centage }\end{array}$ & & \\
\hline $10,000-30,000$ & 27 & 3 & 11.1 & 26489 & 2280 \\
\hline $31,000-50,000$ & 113 & 40 & 35.4 & 41798 & 2880 \\
\hline $51,000-70,000$ & 60 & 40 & 66.7 & 60384 & 3991 \\
\hline $71,000-100,000$ & 30 & 25 & 83.3 & 89455 & 4666 \\
\hline $100,000-$ Above & 11 & 11 & 100.0 & 129883 & 8838 \\
\hline
\end{tabular}

\subsection{Dependency rates (Earners' Ratio) and savings}

Another crucial factor for determining the level of savings of the households is the number of earners in the households. Earners' ratio is calculated as the ratio of number of income earning person in a family to the family size of a household. For, better representation it has to converted in per centage terms. It is assumed that, the numbers of earners govern the income of the households while the number of non-earners or dependents will affect the ratio of consumption to income. According to our hypothesis, when the number of earners increases, the income level also increases and hence more saving. The survey data explains that income of the households increase with the number of earners but not in saving. However, it shows that savings do not proportionately increase with the number of earners. There are total 21 households with earners ratio of 0-25 in the sample. The average saving of these households is Rs.4669 
annually. There are also sample households whose earners' ratio is 26-50. The average saving of these households is Rs. 4087 annually. Further, there are 24 households with earners' ratios of 50-75 in the sample. These households saved only Rs. 3634 on an average annually from their income. Households having 76100 earner ratios show a higher saving of Rs.4689 annually. But our data shows earners' ratio has a negative bearing on the savings of households. It shows that households with more earners save less.

Table 8: Number of Earning Persons in the family and Saving

\begin{tabular}{|c|c|c|c|}
\hline $\begin{array}{c}\text { Earners' } \\
\text { Ratio }\end{array}$ & $\begin{array}{c}\text { Total } \\
\text { Households }\end{array}$ & $\begin{array}{c}\text { Households with } \\
\text { Saving }\end{array}$ & Average Saving \\
\hline $0-25$ & 34 & 21 & 4669 \\
\hline $26-50$ & 127 & 61 & 4087 \\
\hline $51-75$ & 51 & 24 & 3634 \\
\hline $76-100$ & 29 & 13 & 4689 \\
\hline \multicolumn{4}{|l|}{ Source: Calculated by Author from Field Survey Data } \\
\hline
\end{tabular}

\subsection{Determinants of Investment}

There are various factors which affect the investment behaviour of households but in present paper we have included only some factors which are relevant to plantation community. These factors are education, occupation and income.

\subsection{Education and investment}

The education of the head of the household also indirectly influences on the investment behaviour of the sample household. In our survey it shows that there is a positive relationship between saving and level of education of the head of the households. Household head with no education and primary education have lower investment both in education and other income generated activities (Table 9). The average investment of households' heads with middle and high school education showed higher as compared to the head of the household with 
no education and primary education. These households invest more on both in education and other income generated activities. Further, household head with above matriculation degree showed higher investment both in children's education and other income generated activities among the sample workers. Similarly, household head with graduate level of education have higher investment among the sample workers. It shows the positive relationship between education of the head of the households and investment rate. Thus, it is clear that, more educated head of the household invest more as compared to with less educated head of the households.

Table 9: Educational Status of Respondents and their Investment

\begin{tabular}{|l|c|c|c|}
\hline $\begin{array}{c}\text { Level of } \\
\text { Education }\end{array}$ & $\begin{array}{c}\text { Average } \\
\text { Investment in } \\
\text { Education }\end{array}$ & $\begin{array}{c}\text { Average } \\
\text { Investment in } \\
\text { Other Activities }\end{array}$ & $\begin{array}{c}\text { Total Average } \\
\text { Investment }\end{array}$ \\
\hline Illiterate & 4105 & 4382 & 4646 \\
\hline Primary & 3116 & 2750 & 4033 \\
\hline Middle & 5714 & 2473 & 6460 \\
\hline High School & 6478 & 6604 & 7916 \\
\hline Class XI-XII & 7333 & 12250 & 15500 \\
\hline BA and Above & 9500 & 11600 & 21100 \\
\hline \multicolumn{4}{|l|}{ Source: Calculated by Author From Field Survey Data } \\
\hline
\end{tabular}

\subsection{Occupation and investment}

Investment of sample households in the sample gardens are largely influenced by their occupation. As maximum tea gardens workers in the sample are engaged in manual works, they find very difficult to take up the investment plan. Fixed salary holders workers like, sardars, drivers, office staffs and clerk earn higher income and hence go for more investment plan. The investment of sample households according to the occupation of head of the households is given in Table 10. According to data given in the table it is found that occupation of head of the household affect the investment behaviour of sample household in tea gardens. It shows that better the occupation of the head of the household, the higher in the investment and vice-versa. 
Table 10: Occupation of Head of the Households' and Income and Investment

\begin{tabular}{|l|c|c|c|c|c|}
\hline Occupation & $\begin{array}{c}\text { Total } \\
\text { HH }\end{array}$ & $\begin{array}{c}\text { No. HH with } \\
\text { Investment }\end{array}$ & $\begin{array}{c}\text { \% share of } \\
\text { the total } \\
\text { workers }\end{array}$ & $\begin{array}{c}\text { Average } \\
\text { Income }\end{array}$ & $\begin{array}{c}\text { Average } \\
\text { Investment }\end{array}$ \\
\hline Manual Workers & 163 & 112 & 68.7 & 22479 & 4802 \\
\hline Agri Workers & 15 & 14 & 93.3 & 23901 & 4027 \\
\hline Sardars & 10 & 10 & 100.0 & 29782 & 6078 \\
\hline Clerk & 21 & 19 & 90.5 & 34421 & 7688 \\
\hline Drivers & 11 & 8 & 72.7 & 41320 & 8313 \\
\hline Business & 9 & 8 & 88.9 & 41200 & 10400 \\
\hline Office Staffs & 12 & 12 & 100.0 & 61765 & 15383 \\
\hline \multicolumn{5}{|l|}{ Source: Calculated by Author from Field Survey Data, 2011 } \\
\hline
\end{tabular}

Thus, households head with better occupation has higher income and hence induce more in investment. It is further found that, manual workers and agricultural workers earn less income as compared to fixed salary earners in the sample. As they are not fixed salary earners, their income fluctuate every year. During off-season they find difficult to get work hence reduce total income. Therefore, these workers are not able to take up the investment plan.

\subsection{Income and investment}

Income is another most important factor which affects the investment behaviour of the sample households. In the present study, to examine the effect of income on investment we have classified entire sample workers in different income groups. The calculated results show that income has a positive impact on investment (Table 11). It shows that households with higher income have higher average investment among the sample workers. Many households in the sample are under the income group range of Rs. 30,000 to 50,000 per annum. These households invest on an about Rs.4780 annually. Further, the households with an income level of above one lakh have much higher investment. These households invest on an average about Rs. 13840 in a year. Thus, it is clear that households 
160 | PRAGATI: Journal of Indian Economy

having higher level of income are recorded to have more investment in all the sample gardens.

Table 11: Average Income and Investment of Different Income Groups

\begin{tabular}{|c|c|c|c|c|c|}
\hline \multirow[t]{2}{*}{ Income Groups } & \multirow{2}{*}{$\begin{array}{c}\text { No. } \\
\text { of } \\
\text { HH }\end{array}$} & \multicolumn{2}{|c|}{ HH with Investment } & \multirow{2}{*}{$\begin{array}{l}\text { Average } \\
\text { Income }\end{array}$} & \multirow{2}{*}{$\begin{array}{c}\text { Average } \\
\text { Investment }\end{array}$} \\
\hline & & $\begin{array}{l}\text { Total } \\
\mathrm{HH}\end{array}$ & Per cent & & \\
\hline $10,000-30,000$ & 27 & 16 & 59.25 & 23264 & 3476 \\
\hline $31,000-50,000$ & 113 & 79 & 69.91 & 38947 & 4780 \\
\hline $51,000-70,000$ & 60 & 52 & 86.66 & 58277 & 7063 \\
\hline $71,000-100,000$ & 30 & 30 & 100.00 & 87000 & 13390 \\
\hline 100,000 - Above & 11 & 11 & 100.00 & 107580 & 13840 \\
\hline
\end{tabular}

\subsection{Estimated Result and Analysis}

Since the data is cross sectional in nature and panel data analysis (STATA11) has been suitable in its analysis. The sample size of 119 is available for regression in order to find out linear relationship between independent variables and dependent variable. The estimated result of saving function is given in Table 12. The questionable feature of result given above is low value of $R$ square which is 0.25 . Normally for a good result it should be close to 1 ; however for this analysis it is low. It means the above given independent variables can occupy 25 per cent of the dependent variable. In this estimation, the main determinants (economic in character) such as rate of interest can't be incorporated since there is a lack of proper information on various saving schemes for garden workers. Among the independent determinant variables, income is the only variable which is significant bearing value 5.14 greater than 2; and the rest variables are not significant since their value are less than 2. As shown in Table 12, the coefficient of income is 0.71 approximately. This means that when there is a $1 \%$ per cent increase in the value of income of a garden worker, there is a 0.71 per cent increase in the value of saving. Similarly, when level of education increases by 1 per cent, the savings rate increases by 0.093 per 
cent. Further, when the earner ratio increases by 1 per cent, saving level increases by 0.01 per cent. However, both education and earner ratio are not satisfactorily significant.

Table 12: Saving Function (Insaving) Estimation Results

\begin{tabular}{|c|c|c|c|c|}
\hline Variable & Coefficient & Std. Error & $\mathbf{t}$ & P>t \\
\hline Inincome & 0.714 & 0.139 & 5.14 & 0.00 \\
\hline Lnedu & 0.093 & 0.082 & 1.13 & 0.26 \\
\hline lnratioear & 0.011 & 0.127 & 0.09 & 0.932 \\
\hline Cons. & 0.156 & 1.391 & 0.11 & 0.911 \\
\hline
\end{tabular}

No. obs. $=119 ;$ R Squared $=0.25$, Adj. $R$ squared $=0.23$

Note: lnsaving = Log of saving; lnincome = Log of worker's total income from all sources; lnratioear $=$ Log of ratio of earner's ratio; $\operatorname{lnedu}=\log$ of Educational attainment;

Further, for the estimation of investment the number of sample size available is 158 and estimation is held in STATA11 to find linear relationship. The estimation result has been shown in Table 13. The estimation result shows that the value of $\mathrm{R}$ Squared is found less i.e. 0.33 which means that the above given independent variables occupy 33 per cent of determinants variables. Among the determinant variables, income and education are found significant (their values are more than 2). Coefficient of income is 0.97 which means that a 1 per cent increase in income will lead to 0.97 per cent increase in investment. Similarly, when worker's education increase by 1 per cent, investment increases by 0.24 per cent. The subsidiary ratio is not significant.

Table 13: Investment Function (Ininvest) Estimation Results

\begin{tabular}{|c|c|c|c|c|}
\hline Variable & Coefficient & Std. Error & $\mathbf{t}$ & P>t \\
\hline Lnincome & 0.979 & 0.141 & 6.93 & 0.00 \\
\hline lnratiosub & 0.017 & 0.039 & 0.44 & 0.662 \\
\hline Lnedu & 0.242 & 0.095 & 2.54 & 0.012 \\
\hline Cons & -2.401 & 1.529 & -1.57 & 0.119 \\
\hline
\end{tabular}

R Squared=0.33; Adjusted R Squared $=0.32$

Note: $\operatorname{lninvest}=$ Log of workers' investment; lnincome $=$ Log of worker's total income from all sources; lnratiosub $=$ Log of ratio of workers' subsidiary income to all sources of income; lnedu $=$ Log of education attainment of worker 
162 | PRAGATI: Journal of Indian Economy

\subsection{Conclusion}

The paper found that there is propensity to save and invest among tea gardens workers despite low income. Factors like levels of income, education status, occupation have positive influence on saving; the number of dependents exerts a negative influence on saving. The factors that are usually regarded as the determinants of investment behaviour are income level, age, education status, occupations, number of dependents, expenditure and saving of household head. The study also found that there is positive relationship between saving and level of education of head of the households. This indicates that higher level of education is associated with better occupation, higher income and hence higher saving. The occupation of the head of the household plays an important role in differentiating saving among the households. The estimated result of coefficient of income indicates that higher the level education, the higher will be the income earning. As a 1 per cent increase in income will lead to 0.97 per cent increase in the unit investment of the worker in the sample gardens; similarly, a 1 per cent increase in income would lead to a 0.71 per cent increase in savings. Hence this paper at last concludes the importance of education for workers in order to persuade them to save and invest.

\section{References}

Athukorala, Prema Chandra \& Sen, Kunal. (2001). The determinants of private saving in India. Working Papers in Trade and Development, Published by Division of Economics, Research School of Pacific and Asian Studies

Bhalla, S.S. (1980). The measurement of permanent income and its applications to saving. Journal of Political Economy, 88(4): 722-744.

Friend, Irvin. (1966). The propensity to save in India. In Butani and Singh (eds), Economic Development, Issues and policies', Bombay Vora and Co.Publishers Pvt. Ltd 
Horioka, C. Y. \& Wan, J. (2007). The determinants of household saving in China: A dynamic panel analysis of provincial data. Working Paper Series No 2723 of National Bureau of Economic Research

Issahaku, Haruna. (2011). Determinants of savings and investment in deprived district capitals of Ghana: A case study of Nadowli in the upper West region of Ghana. Continental Journal of Social Science, 4(1): 1-11.

Kibet Lawrence K, Mutai B.K, Desterio E. O, Shem A. Ouma \& George, Owuor (2000). Determinants of household saving: Case study of smallholder farmers, entrepreneurs and teachers in rural areas of Kenya. Journal of Development and Agricultural Economics, 1(7): 137-143.

Kraay, Aart (2000). Household saving in China. The World Bank Economic Review, 14(3): 545-570.

Krishnamurthy, K \& P. Saibaba. (1981). Determinants of saving rate in India. Indian Economic Review, XIV(4): 225-249.

Krishnamurthy, K. (1966). Consumption function for India: A macro-time series study. The Indian Economic Journal, XIII(2): 138.

Leff, Nathaniel, H. (1969). Dependency ratios and saving rates. American Economic Review, 59(5): 231-233.

Loayza, Norman V., Schmidt-Hebbel, Klaus \& Servén, Luis (2000). Saving in developing countries: An overview. The World Bank Economic Review, 14(3): 393-414.

Mody, A (1983). Rural resources generation and mobilization. Economic and Political Weekly, 18(19/21): 789-824. 
164 | PRAGATI: Journal of Indian Economy

Panickar; P. G. K. (1992). Rural household savings and investment: A case study of some selected villages in Kerala and Tamil Nadu. Center for Development Studies Publishers, Occasional Paper Series, Trivandrum.

Raj, K.N. (1962). The marginal rate of savings in the Indian economy. Oxford Economic Papers, 14(1): 36-40.

Repetto, Robert \& Shah, Vimal (1975). Demographic and Other Influences on Long-term Saving Behaviour in Rural Development Block in India. Ahmedabad Gujarat Institute of Area Planning.

Rogg, Christian S. (2000). The Impact of Access to Credit on the Saving Behaviour of Micro-entrepreneurs: Evidence from 3 Latin American Countries. Inter American Development Bank Publishers. 